\title{
И.Н. Шамина
}

\section{СОЦИАЛЬНЫЙ ПОРТРЕТ МОНАШЕСТВУЮЩИХ КОЛОМЕНСКОЙ ЕПАРХИИ В КОНЦЕ XVII — НАЧАЛЕ XVIII В.}

\begin{abstract}
Аннотация В статье на основе переписных книг монастырей Коломенской епархии 1701-1702 гг. проведено изучение социального состава монашествующих 12 обителей, входивших в состав епархии на рубеже XVII и XVIII вв. Рассмотрены вопросы о времени и месте пострига монахов, проанализированы данные о социальном статусе их семей и месте проживания до поступления в монастырь, занятиях и др.

Ключевые слова: Коломенская епархия, монастырские переписные книги, социальный состав монашествующих.

Summary Based on the census books of the monasteries of the Kolomna diocese of 1701-1702, the article examines the social composition of the monks of 12 monasteries that were part of the diocese at the turn of the XVII and XVIII centuries. Questions about the time and place of the monks' vows are considered, data on the social status of their families and the place of residence before entering the monastery, classes, etc. are analyzed.

Keywords: Kolomna diocese, monastic census books, social composition of the monks.
\end{abstract}

Православные монастыри на протяжении всей истории Русского государства играли существенную роль. Они являлись не только крупными вотчинниками, но и центрами культуры, велико было их социальное значение. И.К. Смолич установил, что к 1724 г. в Российском государстве насчитывалось 14534 монаха и 10673 монахини ${ }^{1}$. Несмотря на то что в структуре общества XVII-XVIII в. это была весьма существенная по численности группа населения, вопрос о том, представители каких сословий чаще всего и в связи с чем стремились уйти в монастыри, до сих пор относится к числу малоизученных.

1 Смолич И.К. Русское монашество, 988-1917. Жизнь и учение старцев. М., 1999. С. 563. 
О социальном и географическом происхождении монахов XVII столетия в историографии имеются лишь отдельные упоминания, касающиеся прежде всего уникальных в этом отношении обителей. Так, о московском Андреевском, «что во Пленницех», монастыре, основанном Ф.М. Ртищевым, известно, что там, наряду с русскими, селились монахи из украинских, белорусских, литовских и других православных монастырей ${ }^{2}$ О происхождении пострижеников Воскресенского Новоиерусалимского монастыря со ссылкой на патриаршего келейника Ивана Шушерина упомянула В.С. Румянцева: «В Воскресенском монастыре... в то время пребываху даже многие иноземцы греки и поляки, черкасы и белорусцы, и новокрещенные немцы и жиды» ${ }^{3}$, а в Иверский на Валдае монастырь в 1655 г. были переведены более 70 монахов из упраздненного белорусского Кутеинского оршанского монастыря 4 и др. Анализ отдельных сторон социального происхождения насельников вологодских монастырей XVII-XVIII вв. был предпринят составителями издания «Переписные книги вологодских монастырей XVI-XVIII вв.» ${ }^{5}$.

Несколько более изучен вопрос о социальном составе монашествующих XVIII столетия. Так, некоторые обобщающие наблюдения о ситуации, сложившейся в это время, сделала Е.Б. Емченко. По ее мнению, в XVIII в. социальный состав монашествующих мужчин и женщин различался, что во многом объяснялось государственной политикой по отношению к монашеству. В мужских монастырях было традиционно много выходцев из духовного сословия, в то время как в женских, располагавшихся, как правило, в городах или вблизи них, преобладали представительницы дворянского, купеческого и мещанского сословий ${ }^{6}$.

Социальный и гендерный состав монашествующих на примере Урала и Перми проанализировала Е.В. Кустова. Используя в первую очередь данные ведомостей 1724 г., она выяснила, что «особенностью Приуралья было фактическое отсутствие среди братии представителей дворянства

2 Румянцева В.С., Даниленко В., прот. Андреевский монастырь в Пленницах // Православная энциклопедия. М., 2001. Т. 2. С. 350.

3 Румянцева В.C. Монастыри и монашество в XVII веке // Монашество и монастыри в России. XI-XX века: Исторические очерки. М., 2002. С. 176.

4 Жервэ Н.Н. Валдайский Святоозерский в честь Иверской иконы Божией Матери мужской монастырь // Православная энциклопедия. М., 2003. Т. 6. С. 615.

5 Башнин Н.В., Черкасова М.С., Шамина И.Н. Описи вологодских монастырей как источник по аграрной и демографической истории // Переписные книги вологодских монастырей XVI-XVIII вв.: исследование и тексты / Изд. подгот. О.Н. Адаменко, Н.В. Башнин, М.С. Черкасова при участии А.П. Анишиной, Н.А. Бараевой, Е.А. Виноградовой, А.Н. Красикова, С.Н. Смольникова, И.Н. Шаминой. Вологда, 2011. С. 439-444.

${ }^{6}$ Емченко Е.Б. Женские монастыри в России // Монашество и монастыри в России. XI-XX века: Исторические очерки. М., 2002. С. 265-266. 
и боярства», «лутчие люди» «предпочитали принимать постриг в достаточно обеспеченных городских монастырях, благотворителями которых обычно являлись». Исследовательница пришла к выводу о в целом демократичном социальном составе монастырей изучаемого ею региона, включавшем все группы населения ${ }^{7}$. Особенности монашества Среднего Урала в синодальный период рассмотрела М.Ю. Нечаева. Она установила, что в 1722-1724 гг. больше половины монастырских насельников региона принадлежали к крестьянству, 18\% были горожанам, 7\% - выходцами из приходского духовенства, 4\% - представителями служилых сословий. В то же время в Вятской епархии 78\% монахов составляли жители городов, а в далматовских обителях Зауралья преобладали иноки из служилых людей ${ }^{8}$.

В целом же вопрос о социальном происхождении монашествующих в конце XVII - начале XVIII в. остается малоизученным. Важным источником, позволяющим осветить эту проблему, являются монастырские переписные книги. Несмотря на активное их изучение и публикацию в последние годы ${ }^{9}$, переписные книги как источник по социальному происхождению монахов

7 Kустова Е.В. Монастыри и монашество в социокультурной истории Приуралья в середине XVI - первой четверти XVIII в. Дис. ... д-ра ист. наук. Киров, 2017. Т. 2.

${ }_{8}$ Нечаева М.Ю. Монашество Среднего Урала синодального периода: принципы формирования и социальный состав. Екатеринбург, 2019. С. 30, 31.

9 См. например: Отписная книга Введенского Корнильево-Комельского монастыря переписи В.Г. Данилова-Домнина, составленная при передаче монастыря игумену Рафаилу и келарю Александру 2 декабря 1657 г. / Публ. Ю.С. Васильева // Городок на Московской дороге: Историко-краеведческий сборник. Вологда, 1994. С. 130-169; Дмитриева 3.В. Вытные и описные книги Кирилло-Белозерского монастыря XVI-XVII вв. СПб., 2003; Описи Соловецкого монастыря XVI в.: Комментированное издание / Сост. З.В. Дмитриева, Е.В. Крушельницкая, М.И. Мильчик, отв. ред М.И. Мильчик. СПб., 2003; Опись строений и имущества Кирилло-Белозерского монастыря 1601 года: Комментированное издание // Сост. 3.В. Дмитриева, М.А. Шаромазов. СПб., 1998; Опись строений и имущества Кирилло-Новоезерского монастыря 1657 г. / Публ. Т.В. Сазоновой // Белозерье. Краеведческий альманах. Вып. 2. Вологда, 1998. С. 130-165; Соколова Н.В. Описание церковно-монастырских владений в процессе секуляризации начала XVIII в.: Опыт реконструкции (на материалах Нижегородского уезда)// Северо-Запад в аграрной истории России: Межвузовский тематический сборник научных трудов. Калининград, 2008; Шамина И.Н. Преподобный Иннокентий Комельский и основанный им монастырь // Вестник церковной истории. 2009. № 1/2(13/14). С. 26-99; Шамина И.Н. Опись имущества вологодского Павлова Обнорского монастыря 1701-1702 годов // Вестник церковной истории. 2010. № 1/2(17/18). С. 17-107; Переписные книги вологодских монастырей XVI-XVIII вв...; Шамина И.Н. Документы по истории Григориева Пельшемского монастыря XVII - начала XVIII в. // Вестник церковной истории. 2011. № 3/4(23/24). С. 30-63; Башнин Н.В. Опись имущества и строений Дионисиева Глушицкого монастыря 1701 г. и переписные книги вотчины Дионисиева Глушицкого монастыря 1702 г. // Вестник церковной истории. 2013. № 3/4(31/32). С. 138-177; Шамина И.Н. Переписные книги коломенских Спасо-Преображенского, Голутвина, Бобренева и Брусенского монастырей 1701 г. // Вестник церковной истории. 2017. № 3/4(47/48). С. 96-226; Шамина И.Н. Переписная книга вологодского Спасо-Нуромского монастыря и его вотчины 1701-1702 гг. // Вестник церковной истории. 2020. № 1/2(57/58). С. 5-37; и др. 
российских монастырей остаются недооцененными. Между тем в них содержится подчас уникальная информация по интересующей нас теме.

В настоящей статье предпринята попытка охарактеризовать состав монашествующих Коломенской епархии на рубеже XVII и XVIII вв. по переписным монастырским книгам 1701-1702 гг. Описание монастырей Российского государства в 1701-1703 гг. ${ }^{10}$ проводилось по инициативе правительства Петра I в связи с передачей дел воссозданному в 1701 г. Монастырскому приказу. Вместе с монастырями описывались также архиерейские дома и приходские церкви. Перепись начала XVIII в. являлась одним из этапов практической реализации церковной реформы, направленной на частичную секуляризацию церковно-монастырского землевладения и хозяйства. Дошедшие до наших дней переписные книги 1701-1703 гг. хранятся преимущественно в фонде Монастырского приказа (РГАДА, ф. 237).

Историки неоднократно обращались к материалам этого описания. В частности, Е.Н. Швейковская изучала переписные книги Вологодского архиерейского дома и Спасо-Прилуцкого монастыря. Она отметила, что в ходе переписи начала XVIII в. «учету подлежали вся церковная утварь, одежда, книги, казна, а также акты, на основании которых монастырь или архиепископский дом владел своими землями и деревнями. Основной упор при переписи делался на выяснение всех статей дохода в церковной вотчине» ${ }^{11}$.

Коломенская епархия была учреждена в середине XIV в. В ее состав входили земли центральных и южных уездов страны. К середине XVII в. это, как писал Павел Алеппский, была «беднейшая из всех архиерейских кафедр в стране Московской» ${ }^{12}$. К концу XVII в. ее земли располагались в ряде центральных и южных уездов государства - Коломенском, Каширском, Тульском, Орловском, Крапивенском и др.

Составление переписных книг монастырей Коломенской епархии, как и большинства других регионов Российского государства, проходило в 1701-1702 гг. Сохранившиеся описания вошли в книгу 58 (РГАДА, ф. 237, оп. 1, ч. 1). В это время в составе епархии находились 12 обителей (9 мужских и 3 женских), однако их переписные книги составляли разные переписчики. Коломенские Спасо-Преображенский, Голутвин, Бобренев, Бру-

${ }^{10}$ И.А. Булыгин датирует описание 1701-1705 гг. (Бульгин И.А. Монастырские крестьяне России в первой четверти XVIII в. М., 1977. С. 35).

${ }^{11}$ Бакланова [Швейковская] E.Н. Крестьянский двор и община на Русском Севере. Конец XVII - начало XVIII в. М., 1976. С. 52.

${ }^{12}$ Павел Алеппский. Путешествие антиохийского патриарха Макария в Россию в половине XVII века, описанное его сыном, архидиаконом Павлом Алеппским / Пер. Г.А. Муркос. M., 2005. C. 226-227. 
сенский, тульские Иоанно-Предтеченский и Успенский монастыри, а также каширские Соколову, Саввину (Березину) и Николаевскую на Гнилуше в Коломенском уезде пустыни наряду с Коломенским архиерейским домом описывал стольник Иван Васильевич Кикин (1660-1723 гг.); орловские Введенский и Успенский монастыри, а также Троицкий монастырь в Крапивне - стольник Михаил Толубеев.

Следует заметить, что переписные книги российских монастырей 17011703 гг. по содержанию несколько отличаются друг от друга. Видимо, единого строгого формуляра не существовало, и объем информации по тому или иному пункту описания устанавливал сам переписчик. Это относится, в частности, и к разделу о монахах. Так, стольник В.И. Кошелев, составлявший переписные книги вологодских монастырей, перечисляя монахов указывал их имена, род занятий и место жительства до пострига, место принятия иноческого сана и должность в монастыре ${ }^{13}$. Многие переписчики, как, например, служки Троице-Сергиева монастыря, описывавшие приписные к Троице Белопесоцкий и Алатырский монастыри, перечислили имена монахов, упустив другие сведения о них ${ }^{14}$. Стольник же В.Р. Воейков, направленный в Углич и Угличский уезд, зафиксировал лишь имена настоятелей и назвал число остальных насельников ${ }^{15}$.

Описания же части монастырей Коломенской епархии (расположенных в Коломне, Туле, а также Коломенском и Каширском уездах), составленные И.В. Кикиным, в этом смысле наиболее подробны. В частности, в каждом случае стольник привел не только имена монахов, но также время и место их пострига, сведения о семье и месте проживания, занятиях или социальном статусе до поступления в монастырь. Из описаний можно узнать о переходе монахов из других монастырей, о женщинах есть указания на то, были ли они до прихода в монастырь замужем или постриглись незамужними.

В то же время переписные книги других монастырей Коломенской епархии - орловских и крапивенского, - составленные Михаилом Толубеевым, более краткие. Информация о монахах, как и в отмеченных выше приписных обителях Троице-Сергиева монастыря, включает лишь их имена.

\footnotetext{
${ }^{13}$ См., например, переписные книги Спасо-Каменного и сямженского Спасо-Евфимиева монастыря (Переписные книги вологодских монастырей... С. 154-155, 251), Павлова Обнорского (Шамина И.Н. Опись имущества вологодского Павлова Обнорского монастыря... С. 85-88) и др.

${ }^{14}$ РГАДА. Ф. 237. Оп. 1. Ч. 1. Кн. 40. Л. 430-430 об.; Алатырский Троицкий мужской монастырь. Документы 1612-1703 годов / Сост. В.Д. Кочетков, А.А. Чибис. Ульяновск, 2015. C. $328-329$.

${ }^{15}$ Углич: материалы для истории города XVII и XVIII столетий. М., 1887. С. 176 и др.
} 
Следовательно, в центре внимания настоящей статьи будут находиться в первую очередь монастыри Коломны, Тулы, а также Коломенского и Каширского уездов.

Переписные книги монастырей Коломенской епархии 1701-1702 гг. позволяют в первую очередь установить численность пострижеников. Наиболее населенным в эти годы был орловский женский Введенский монастырь, в нем перечислена 41 монахиня. К числу крупных можно отнести также тульские Успенский женский (40 монахинь) и Иоанно-Предтеченский мужской (36 монахов) монастыри. Чуть меньше монахов жило в коломенских Голутвине (28) и Брусенском женском (26) монастырях, а также в Успенском монастыре Орловского уезда (20). Численность монашествующих в остальных обителях составляла от 15 человек в Троицком крапивенском и 12 в коломенском Спасо-Преображенском до 8 человек в коломенском Бобреневе монастырях. В Николаевской пустыни на реке Гнилуше на момент описания проживали 7 пострижеников, в каширской Саввине пустыни указан лишь один строитель, а каширская Соколова пустынь к началу XVIII в. и вовсе осталась без насельников: «В тои-де пустыне строителей и монахов нет прошлаго 1701-го году с марта месяца» ${ }^{16}$.

В целом в начале XVIII в. монастырях Коломенской епархии жили 234 постриженика. Среди них 107 человек (около 46\%) составляли женщины. Как видим, численность монахинь и монахов была примерно одинаковой, в то время как женские монастыри оказались более населенными, чем мужские. К подобному выводу пришла и Е.Б. Емченко, касаясь более позднего периода. Она показала, что женские монастыри, «будучи более многочисленными, чем мужские... были крайне бедными и получали дотацию от государства» ${ }^{17}$. В переписных книгах монастырей Коломенской епархии должности, выполняемые монахами в обители, не указаны. Отмечены только настоятели, казначеи, иеромонахи и иеродиаконы, названы имена рядовых монахов. В женских монастырях постриженицы делятся на монахинь и схимонахинь. В ряде случаев лиц, занимавших некоторые монастырские должности, можно установить по отдельным упоминаниям или по скрепам. Так, например, в описании коломенских Спасо-Преображенского и Голутвина монастыря упоминаются конюшенные и житенные старцы.

Из содержания переписных книг следует, что подавляющее большинство монахов (88\%) приняли постриг в том монастыре, где находились на момент составления описания.

${ }^{16}$ РГАДА. Ф. 237. ОП. 1. Ч. 1. Кн. 58. Л. 435 об.

${ }^{17}$ Емченко Е.Б. Женские монастыри в России. С. 258-259. 
Таблица 1.

Место пострига монахов Коломенской епархии

\begin{tabular}{|c|c|c|c|}
\hline Монастыри & Всего монахов & $\begin{array}{c}\text { Постриглись в том же } \\
\text { монастыре }\end{array}$ & $\begin{array}{c}\text { Постриглись в других } \\
\text { монастырях }\end{array}$ \\
\hline Успенский & $40(100 \%)$ & $37(92,5 \%)$ & $3(7,5 \%)$ \\
\hline Иоанно-Предтеченский & $36(100 \%)$ & $34(94 \%)$ & $2(6 \%)$ \\
\hline Богоявленский Голутвин & $28(100 \%)$ & $22(79 \%)$ & $6(21 \%)$ \\
\hline Брусенский & $26(100 \%)$ & $25(96 \%)$ & $2(4 \%)$ \\
\hline Спасо-Преображенский & $12(100 \%)$ & $10(83 \%)$ & $2(25 \%)$ \\
\hline Бобренев & $8(100 \%)$ & $6(75 \%)$ & $2(29 \%)$ \\
\hline Николаевская пустынь & $7(100 \%)$ & $5(71 \%)$ & $1(100 \%)$ \\
\hline Саввина пустынь & $1(100 \%)$ & - & $19 \%)$ \\
\hline Всего по монастырям & $158(100 \%)$ & $139(88 \%)$ & \\
\hline епархии & & & \\
\hline
\end{tabular}

Число монахов, перешедших из других обителей, независимо от размера монастыря, - не более двух человек. Исключение составляет лишь Голутвин монастырь, где таких пострижеников оказалось в три раза больше. В большинстве случаев перешедшими из других обителей отмечены настоятели.

B XVI в. в соответствии с монастырскими уставами настоятелей избирали сами монахи, затем их кандидатуру утверждал епархиальный архиерей. Однако в XVII в. настоятели стали назначаться архиереем. Об этом прямо говорится в переписной книге Саввиной пустыни Каширского уезда: строитель Паисий «пострижен в Троицком Белопесоцком монастыре, а в тои-де Савиной пустыни по архиерейскому указу живет он третей год» ${ }^{18}$.

Игумен тульского Иоанно-Предтеченского монастыря Корнилий начал свой монашеский путь в 1661 г. в коломенском Голутвине монастыре, после чего был назначен игуменом в Троицкий монастырь в Кромах (по крайней мере до середины XVII в. Кромы входили в состав Коломенской епархии ${ }^{19}$ ) и спустя два года, в начале 1670-х гг, возглавил Предтеченский монастырь ${ }^{20}$. Однако, видимо, управлял он этим монастырем с перерывом. Некоторое время, до 1701 г., игуменом Предтеченского монастыря был Сильвестр - будущий настоятель коломенского Бобренева монастыря: «А он, Силивестр... пострижен на Туле в Предтечеве монастыре тому десять лет и в том монастыре был игуменом. А в Бобренев монастырь переведен ис того Предтечева

${ }^{18}$ РГАДА. Ф. 237. Оп. 1. Ч. 1. Кн. 58. Л. 425.

${ }^{19}$ Печников М.В., Пидгайко В.Г. Коломенская епархия // Православная энциклопедия. М., 2014. T. 36. C. $390-398$.

${ }^{20}$ РГАДА. Ф. 237. Оп. 1. Ч. 1. Кн. 58. Л. 537. 
монастыря в нынешнем 1701-м году в феврале месеце» ${ }^{21}$. Получается, что после него Корнилий вступил в должность настоятеля повторно. В справочнике П.М. Строева игумен Сильвестр не упоминается.

Игумен Голутвина монастыря Иов принял постриг в коломенском Спасо-Преображенском монастыре, был настоятелем в каширском Троицком Белопесоцком монастыре. В архиве последнего в начале XVIII в. хранилась составленная им роспись: «А по той росписи довелось взять Белопесоцкого монастыря вотчин на крестьянех казенных доимочных денег дватцать семь рублев с полтиною» ${ }^{22}$. В 1700 г. Троицкий Белопесоцкий монастырь был приписан к Троице-Сергиеву монастырю. Возможно, это событие и послужило причиной того, что игумена Иова перевели в Голутвин.

Перемещение настоятелей из одного монастыря в другой во второй половине XVII - начале XVIII в. в целом по стране было достаточно распространенным явлением. На примере же рассматриваемых монастырей мы видим, что перевод настоятелей в эти годы совершался лишь в рамках конкретной епархии.

Иную картину наблюдаем при анализе перемещений монахов. Так, монах коломенского Спасо-Преображенского монастыря Авраамий принял иноческий сан в московском Покровском монастыре, «что на убогих доме», и спустя примерно 17 лет перешел в коломенский Спасо-Преображенский монастырь. Монах Пафнутий постригся в Бундурове монастыре ${ }^{23}$, жил в каширской Саввиной пустыни и в Спасо-Преображенский монастырь перешел незадолго до начала его описания.

Монах Матфей пришел в Голутвин монастырь из Болдыревой пустыни Луховского уезда, монах Аввакум - из Липновской пустыни Курского уезда. Последний, судя по всему, в начале 1670-х гг. бывал в Голутвине монастыре, поскольку, как следует из переписной книги, в 1671/72 г. «по указу великого государя из Голутвина монастыря ис козначейства отдан Белоградцкому митрополиту, а у нево был у приказных дел» ${ }^{24}$. С 1699 г. он вновь поселился в Голутвине монастыре. Подавляющее большинство насельниц женских монастырей также приняли постриг в стенах своей обители. Исключение составляют лишь схимонахиня Брусенского монастыря Ефросиния, о которой сказано, что она «пострижена лет 3 дватцеть, а в Брусенском монастыре живет четвертой год», и трое монахинь

${ }^{21}$ Шамина И.Н. Переписные книги коломенских монастырей... С. 206.

22 РГАДА. Ф. 237. ОП. 1. Ч. 1. Кн. 40. Л. 435.

${ }^{23}$ Возможно, имеется в виду Благовещенский Бунырев монастырь, основанный около 1623 г. в 6 км от Алексина и в 52 км от Тулы на берегах рек Вашана и Ока. В 1764 г. упразднен.

${ }^{24}$ Шамина И.Н. Переписные книги коломенских монастырей... С. 52. 
тульской Успенской обители, пришедшие из московского Зачатьевского монастыря.

Наиболее известной личностью, отмеченной в переписной книге Голутвина монастыря как пришедший извне, оказался бывший строитель московского Андреевского монастыря, «что во Пленницех», Авраамий. Старец Авраамий известен как автор «Тетрадей», адресованных Петру I. Он жил в Андреевском монастыре еще при его основателе Ф.М. Ртищеве. «Тетради» старца Авраамия - это, по сути, челобитная о «государственном нестроении», виновником которого он объявил царя. В 1696 г. Авраамий попытался передать свое сочинение Петру I, а в 1697 г. в Преображенском приказе началось следствие. В результате Авраамий был сослан в Голутвин монастырь «под начал». Уже находясь в Голутвине, в 1701 г. Авраамий отправил Петру I новое письмо, в котором просил забрать его к Москве. После этого следствие возобновилось ${ }^{25}$. По мнению В.С. Румянцевой и протоиерея Б. Даниленко, старец Авраамий попал в опалу и был сослан в Коломну за участие в тайном кружке молодых подьячих, действовавшем в Андреевском монастыре в первой половине $1690-$ х гг. ${ }^{26}$

Прямых указаний на причины смены монастыря другими монахами, кроме монаха Авраамия, в переписных книгах нет. В одном случае, правда, можно предположить, чем могло быть вызвано такое перемещение. Так, о монахе Спасо-Преображенского монастыря Коломны Пафнутии сказано, что он прибыл из каширской Саввиной пустыни и живет в коломенском монастыре «третей год». Так же, «третей год» по указу архиепископа Саввиной пустынью управлял строитель Паисий, назначенный туда по архиерейскому указу ${ }^{27}$. Возможно, по архиерейскому указу, по причине старости или болезни, оттуда был переведен в Спасо-Преображенский монастырь и Пафнутий, а на смену ему назначен Паисий.

Таким образом, перемещения монахов из монастыря в монастырь были редкими, однако не ограничивались пределами одной епархии. Монахи могли переводиться «под начал» в другие монастыри в качестве наказания или по решению архиерея. Возможно, причиной перехода служили и личные мотивы.

Еще один ряд данных, содержащихся в переписных книгах 17011702 гг. - место жительства монашествующих до их пострига. Этот вопрос

${ }^{25}$ Панченко А.М. Авраамий // Словарь книжников и книжности Древней Руси. Вып. 3 (XVII в.). Ч. 1 / Отв. ред. Д.С. Лихачев. СПб., 1992. С. 34-36.

${ }^{26}$ Румянцева В.С., Даниленко Б., прот. Андреевский монастырь в Пленницах // Православная энциклопедия. Т. 2. С. 350.

${ }^{27}$ РГАДА. Ф. 237. Оп. 1. Ч. 1. Кн. 58. Л. 425. 
затрагивала, в частности, Е.В. Кустова, отметив в пермских монастырях высокий процент выходцев из других земель. По мнению исследовательницы, это могло быть связано «с большой активностью сибирского пути и широкой крестьянской колонизацией региона» ${ }^{28}$. Далее в таблицах приводится информация о том, откуда прибыли постриженики монастырей Тулы и Коломны. Расстояние в 400 км использовано в таблице как условная граница относительно близких и дальних к тому или иному монастырю территорий, поскольку в XVII в. путь в 400 км преодолевался достаточно часто и на это уходило примерно 10 дней ${ }^{29}$. Очевидно, что из более дальних мест люди перемещались значительно реже.

Таблица 2.

Место жительства до пострига монахов тульских Иоанно-Предтеченского и Успенского монастырей

\begin{tabular}{|c|c|c|c|c|c|c|}
\hline \multirow[t]{2}{*}{ Регион } & \multicolumn{2}{|c|}{$\begin{array}{c}\text { Иоанно-Предтеченский } \\
\text { монастырь }\end{array}$} & \multicolumn{2}{|c|}{$\begin{array}{c}\text { Успенский женский } \\
\text { монастырь }\end{array}$} & \multicolumn{2}{|c|}{ Всего по Туле } \\
\hline & всего & $\%$ & всего & $\%$ & всего & $\%$ \\
\hline Тула & 9 & 25 & 5 & 12,5 & 14 & 18,4 \\
\hline Тульский уезд & 3 & 8,5 & 3 & 7,5 & 6 & 7,9 \\
\hline $\begin{array}{l}\text { Ближайшие к Тульскому } \\
\text { уезду районы }\end{array}$ & 10 & 28 & 10 & 25 & 20 & 26,3 \\
\hline $\begin{array}{l}\text { Российские города } \\
\text { и уезды, находящиеся } \\
\text { на расстоянии до } 400 \text { км } \\
\text { от Тулы }\end{array}$ & 3 & 8,5 & 2 & 5 & 6 & 7,9 \\
\hline $\begin{array}{l}\text { Российские города } \\
\text { и уезды, находящиеся } \\
\text { на расстоянии свыше } \\
400 \text { км от Тулы }\end{array}$ & 5 & 13,8 & 2 & 5 & 6 & 7,9 \\
\hline $\begin{array}{l}\text { Литовские, польские, } \\
\text { малороссийские города } \\
\text { и уезды }\end{array}$ & 4 & 11 & 1 & 2,5 & 5 & 6,6 \\
\hline Крым & & & 1 & 2,5 & 1 & 1,3 \\
\hline Неизвестно & 2 & 5 & 16 & 40 & 18 & 23,7 \\
\hline Всего монахов & 36 & 100 & 40 & 100 & 76 & 100 \\
\hline
\end{tabular}

В тульском Иоанно-Предтеченском монастыре, как видим из таблицы, большинство монахов происходили из Тулы и ближайших к ней городов

${ }^{28}$ Кустова Е.В. Монастыри и монашество... Т. 2. С. 15.

${ }^{29}$ См.: Башнин H.B. К вопросу о транспортных путях и средствах передвижения в XVII в. (по материалам приходо-расходных книг Вологодского архиерейского дома // Вестник церковной истории. 2018. № 3/4(51/52). С. 303. 
и уездов (Венев, Кашира, Крапивна, Дедилов, Богородицк и др.). Интересно, что здесь жили и выходцы из дальних уездов. В частности, игумен Корнилий был уроженцем Смоленска, но пришел в Тулу из Коломны, где принял постриг в Голутвине монастыре. Казначей Иосиф пришел из Вологды. Он был сыном посадского человека Мефодия Богданова. Оттуда же, из Вологды, пришел в Тулу монах Сафоний, «Николаевскаго Озерскаго монастыря слушкин сын». Монах Иосиф пришел из Ржевы Володимировой, монах Иов - из Смоленского уезда.

Большой интерес представляет группа монахов (5 человек), указавших местом своего рождения Литву или Малороссию. Так, монах Никон сказал, что пришел из «малороссийского Смелого города». Предположительно, это местечко Смела, располагавшееся неподалеку от Киева, на почтовой дороге в Черкасы ${ }^{30}$. Монах Боголеп пришел в Предтеченский монастырь из Вильны, Матфей - сын шляхтича Хриштофа Разнотовского - из «литовского города Лиды» (город в западной части современной Белоруссии, в составе Гродненской области); монах Мисаил — из деревни Гришино вблизи польского населенного пункта Мигновичи (современная Смоленская область).

В переписной книге тульского Успенского женского монастыря местожительство до пострига можно примерно установить лишь для 24 насельниц. Большинство из них, как и в тульском Предтеченском монастыре, прибыли из ближайших к Туле уездов. Среди других городов указаны Москва, Коломна, Ярославль, Чернский и Костромской уезды. Для схимонахини Софии место ее жительства до пострига обозначено как «Черкасские города», монахиня Марфа ранее жила в Крыму, затем попала в плен и позднее оказалась в тульском Успенском монастыре (см. табл. 3).

Большинство пострижеников коломенского Голутвина монастыря пришли из регионов, расположенных на расстоянии до 400 км от монастыря (Москва, Венев, Тверь, Кромский, Костромской, Нижнеломовский уезды и др.). Около трети составляли жители Коломны и Коломенского уезда. В 5 случаях из 28 установить место жительства монахов до поступления в монастырь не удалось. Еще одно из мест жительства можно предположительно установить из сообщения о месте пострига. Так, упоминавшийся выше монах Аввакум принял монашеский сан в Липновской пустыни Курского уезда ${ }^{31}$. Возможно, там, в Курском уезде, и жила его семья. Местом мирского служения монаха Савватия указано село Чиркино Коломенского

\footnotetext{
${ }^{30}$ См.: Похилевич Л.И. Сказания о населенных местностях Киевской губернии, или Статистические исторические и церковные заметки о всех деревнях, селах, местечках и городах, в пределах губернии находящихся. Киев, 1864. С. 643.

${ }^{31}$ Шамина И.Н. Переписные книги коломенских монастырей... С. 155-156.
} 


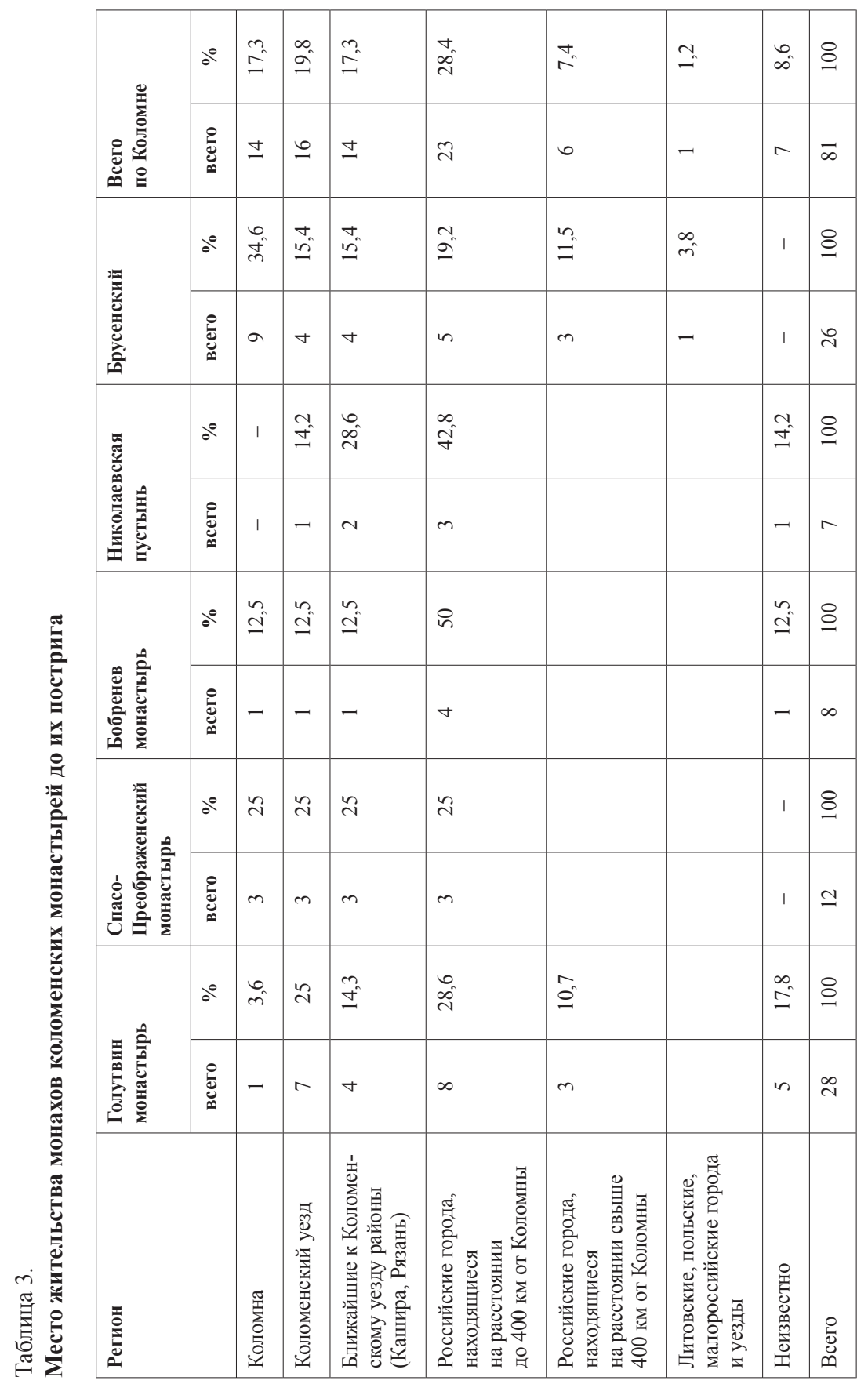


уезда, однако принял постриг он в Тверском Отроче монастыре, где был монастырским слугой его отец, и лишь спустя несколько лет перешел в Голутвин ${ }^{32}$.

В Спасо-Преображенском монастыре одинаковое число монахов поступило из четырех групп территорий. В Бобреневе монастыре большинство монахов (половина от их общего числа) происходили из регионов, находящихся на расстоянии до 400 км от монастыря. В качестве предыдущих их мест жительства указаны Тула, Орел, Орловский и Веневский уезды. О монахе Никите, чье место жительства до пострига в переписной книге не указано, можно предположительно установить из краткой записи о его отце: «Васильев сын курченин». В Николаевскую пустынь на реке Гнилуше желающие принять постриг приходили из Каширского, Алексинского, Суздальского уездов, а также из Каширы и города Михайлова (Рязанский уезд).

В женский Брусенский монастырь, в отличие от мужских обителей города, постриглись в первую очередь жительницы Коломны. Значительная доля принадлежит также выходцам из других российских регионов - Каширы, Москвы, Коломенского уезда, Углича, Нижнего Новгорода, Суздаля, Костромы и др.

В целом же получается, что наибольшее число пострижеников коломенских монастырей происходили из других российских городов, в то время как из Коломны и Коломенского уезда, несмотря на их очевидную близость, монахов поступало меньше.

Переписные книги могут дать ответ и на вопрос, кем были родители пострижеников; часто названы их имена. В ряде случаев, если речь идет о мужских монастырях, также известно, чем занимались до пострига сами монахи. К сожалению, такая информация есть не по каждому человеку, но все же источник позволяет представить социальное происхождение монахов Коломенской епархии в целом. Поскольку данные по мужским и женским монастырям несколько различаются, эти категории будут рассмотрены отдельно.

В тульском Иоанно-Предтеченском монастыре только о четверых монахах известно, кем они были до пострига. Так, иеромонах Авраамий и монах Арсений служили один в Пятницкой церкви села Коптева Тульского уезда, другой — в Никитской церкви Тулы. Монах Митрофан был крестьянином, а монах Антоний «служил по жилецкому списку». Гораздо подробнее информация о родителях монахов. Такие сведения есть о большинстве из них. 10 человек происходили из семей священнослужителей, шестеро

\footnotetext{
${ }^{32}$ Там же. С. 154-155.
} 
были выходцами из крестьян, трое - из семей посадских людей, двое из семей монастырских слуг. В качестве родителей монахов указаны также «торговый человек», солдаты рейтарского строя, городовой тульский дворянин Фома Терентьев Козлов, казак, сын боярский Андрей Брежнев, городовой сын боярский Стефан Кропотов, засечный сторож и др. В одном случае происхождение монаха осталось неизвестным: «Симонов сын, а чей прозванием и какова чину, того сказал не упомнит». Известно лишь, что он прибыл в Тулу из Вильны ${ }^{33}$. Не смог назвать имени своего отца и монах Сафоний, прибывший в Тулу из Вологды. Он был сыном слуги Николаевского Озерского монастыря, однако «как-де отца ево звали, того не помнит, остался в малых летех» ${ }^{34}$. Точно так же, еще ребенком, был взят в монастырь монах Иев: «Из Смоленского уезду взят с малых лет, а с коих мест, того сказать не упомнит» ${ }^{35}$.

Род занятий до поступления в монастырь среди голутвинских пострижеников по переписной книге можно установить для 26 человек. Почти половина из них (12) в миру были священнослужителями, 7 человек служили в домах различных владельцев (у Анны Яковлевны Колтовской, «коломнятина» Никиты Порвоснева у московского истопника И. Спиридонова, в вотчине Белопесоцкого монастыря и др.). Трое монахов до пострига были крестьянами. Указаны также бывшие «приказу Дохтурова пятисотной» и кузнец Оружейной палаты. Монах Сергий до пострига жил в Москве и «кормился черной работой».

Большинство монахов Голутвина монастыря наследовали род занятий своих родителей — становились священнослужителями, работниками в домах помещиков или при монастырях. К выводу о наследственной закрепляемости статуса духовенства, на основе анализа ведомостей устюжских церквей 1720-х гг. пришла и М.С. Черкасова ${ }^{36}$. Однако известны исключения. Так, например, иеромонах Иоасаф был сыном подьячего Московского Судного приказа. Вначале он тоже стал чиновником - подьячим в Коломенской приказной избе, но затем был «ис подьячих посвящен в попы» ${ }^{37}$. Иеромонах Иона - сын посадского человека из Балахны - стал священником в церкви свт. Николая Чудотворца в селе Щира Кромского уезда.

${ }^{33}$ РГАДА. Ф. 237. ОП. 1. Ч. 1. Кн. 58. Л. 541.

${ }^{34}$ Там же. Л. 540 об.

${ }^{35}$ Там же. Л. 539.

36 Черкасова М.С. Демография духовенства Устюжской епархии по данным первой ревизии 1720-1724 гг. // Церковь. Богословие. История: Материалы VII Всероссийской научно-богословской конференции, посвященной 100-летию мученической кончины святых Царственных страстотерпцев и их верных спутников. Екатеринбург, 2019. С. 314-320.

${ }^{37}$ Шамина И.Н. Переписные книги коломенских монастырей... С. 154. 
Монах Ефрем, будучи сыном жителя Тулы, служил священником в селе Шкиня Коломенского уезда и др.

В Спасо-Преображенском монастыре шесть человек до пострига были священнослужителями, двое - крестьянами, один - жителем посада Коломны. Из семей священнослужителей происходила половина пострижеников. 5 из них сами являлись в миру священнослужителями. Один из бывших священников - иеромонах Родион - вышел из семьи коломенского посадского человека. Для двоих монахов Бобренева монастыря установить род занятий в миру по переписной книге не удалось. Пятеро из остальных пострижеников в миру были священнослужителями, один «служил во дворе столника князь Алексея княж Михайлова сына Каркодинова». Монахи - бывшие священнослужители за исключением игумена Сильвестра были детьми священников. Игумен же происходил из семьи «служиваго кормового человека Иоакимова сына Михайлова».

Служили до пострига священниками и трое монахов Николаевской пустыни на Гнилуше, один — «сказал церковнаго дьячка сын» (это единственный случай в этой обители, когда известно об отце постриженика). Монах Ефимий был солдатом, монах Павел «послуживцем Дмитрия Иванова сына Полуехтова». Один из монахов до пострига был крестьянином.

В приведенной ниже сводной таблице в первую очередь учитывается информация о роде деятельности самих монахов. Если таковая отсутствует, принимается во внимание социальное положение его семьи (см. табл. 4).

Таким образом, большинство монахов до пострига были священниками и/или происходили из семей священнослужителей. Служба в церкви являлась наследственной. У родителей-священнослужителей дети, как правило, также становились священниками или диаконами. Существенную долю составляли крестьяне, а также слуги дворян. Достаточно часто в монастыре оказывались представители служилого сословия. Остальные категории населения были представлены в монастырях в меньшей степени. Интересно, что в городских по большей части монастырях оказалось незначительное число жителей посада.

В переписных книгах женских Брусенского и тульского Успенского монастырей информация о занятиях пострижениц в миру является исключением. Как правило, известны только имена отцов и мужей. Если женщина до пострига была замужем, указывались имена и отца, и мужа. Если женщина поступала в монастырь девицей, очевидно, указывался только отец. Так, у 9 монахинь (22,5\%) Успенского монастыря указаны только имена отцов. Для некоторых из них есть уточнение: «пострижена в монастырь девицею». В Брусенском монастыре в 17 случаях из 26 (65\%) известны все эти данные. 


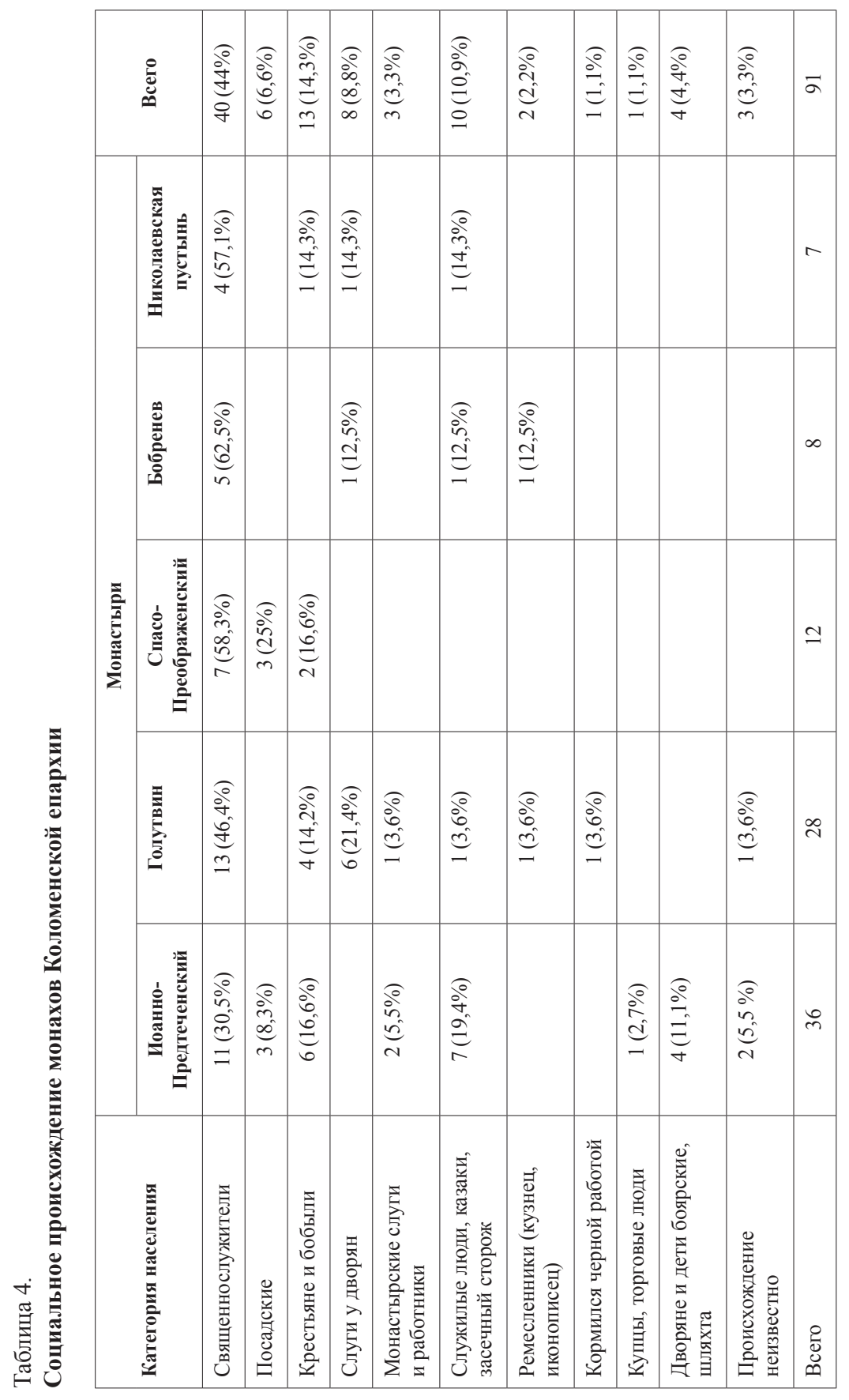


В остальных - только имя отца (мужа) и место их жительства. В Успенском монастыре эти характеристики есть для 9 монахинь (30\% из 30 постриженных замужних). В 5 случаях (16\% из 30) указано, кем были отцы, но неизвестен род деятельности супругов. В почти трети $(31,8 \%)$ случаев в двух монастырях в целом род деятельности родителей или супругов установить не удалось: в переписных книгах сказаны лишь их имена и есть косвенное указание на место, где они жили («углеченин», «коширенин», «туленин»). В приведенной ниже таблице приоритетными считаются данные о занятиях мужей. Если таковых не было, то берутся в расчет сведения о родителях.

Таблица 5.

Социальное происхождение монахинь в монастырях Коломенской епархии

\begin{tabular}{|l|c|c|c|}
\hline & Брусенский монастырь & Успенский монастырь & Всего \\
\hline Посадские & $1(3,8 \%)$ & $3(7,5 \%)$ & $4(6,1 \%)$ \\
\hline чиновники & $3(11,5 \%)$ & & $3(4,5 \%)$ \\
\hline священники & $9(34,6 \%)$ & $3(7,5 \%)$ & $12(18,2 \%)$ \\
\hline крестьяне & $3(11,5 \%)$ & $6(15 \%)$ & $9(13,6 \%)$ \\
\hline $\begin{array}{l}\text { Монастырские } \\
\text { слуги }\end{array}$ & $1(3,8 \%)$ & & $1(1,5 \%)$ \\
\hline $\begin{array}{l}\text { Служилые } \\
\text { люди (пушкарь, } \\
\text { засечный сторож) }\end{array}$ & $2(7,7 \%)$ & $9(22,5 \%)$ & $3(4,5 \%)$ \\
\hline Дворяне, шляхта & $1(3,8 \%)$ & $2(5 \%)$ & $2(3,1 \%)$ \\
\hline $\begin{array}{l}\text { Полонянка, } \\
\text { послуживица }\end{array}$ & $6(23,1 \%)$ & $15(37,5 \%)$ & $21(31,8 \%)$ \\
\hline Неизвестно & 26 & 40 & 66 \\
\hline Всего & & & $2(5 \%)$ \\
\hline
\end{tabular}

Видим, что, как и в мужских монастырях, большинство монахинь также происходили из семей священнослужителей. Так, например, в Брусенском монастыре семь монахинь из 17 вышли из семей, где священнослужителями были отец и муж. Еще в двух случаях служил в церкви лишь один из них. Так, монахиня Евдокия была дочерью священника коломенской соборной церкви, а вышла замуж за подьячего приказа Холопьего суда ${ }^{38}$.

Однако велика доля и тех, чьими мужьями или отцами были служилые люди. В источниках называются рейтары, стрельцы, пушкари, казаки и др. Особенно много женщин из таких семей оказалось в тульском Успенском монастыре.

\footnotetext{
${ }^{38}$ Там же. С. 221.
} 
Трое женщин из обоих монастырей принадлежали к привилегированному сословию. Так, схимонахиня Брусенского монастыря Таисия была дочерью шляхтича «Луцкого города» Якова Берташевича. Монахиня Успенского монастыря Агрипена, родившись в крестьянской семье в Тульском уезде, вышла замуж за своего господина — «Заупского стану того ж помещика Герасимовская жена Трифонова ${ }^{39}$. Монахиня того же монастыря Ираида приходилась дочерью князю Федору Засекину, а замуж вышла за некоего Никиту Палицына. Схимонахиня София, попавшая в Тулу из «Черкасских городов», сообщила, что «отца своего не помнит». Не указаны и родственники крымской полонянки монахини Марфы. Но о последней сказано, что она была «послуживицей Авакума Иевлева».

Возраст монахов в переписных книгах не указан, но можно установить, как давно они приняли иноческий сан и живут в данном монастыре. В некоторых случаях дата пострига написана, в других ее можно установить, исходя из записей: «в монастыре тому три года», «пострижен в том монастыре нынешняго году», «пострижен тому другой год» и т. д. В приведенной ниже таблице время, прошедшее после пострига, условно разделено на несколько периодов: от 0 до 4 лет, от 5 до 10 лет, от 11 до 15 лет, более 15 лет.

Таблица 6.

Срок нахождения монахов в монастыре

\begin{tabular}{|l|c|c|c|c|c|c|}
\hline \multicolumn{1}{|c|}{ Монастырь } & $0-4$ года & $5-10$ лет & $11-15$ лет & $\begin{array}{c}\text { Более } 15 \\
\text { лет }\end{array}$ & $\begin{array}{c}\text { Время } \\
\text { пострига } \\
\text { неизвестно }\end{array}$ & Всего \\
\hline Успенский & $15(37,5 \%)$ & $1(27,5 \%)$ & $7(17,5 \%)$ & $5(12,5 \%)$ & - & 40 \\
\hline $\begin{array}{l}\text { Иоанно- } \\
\text { Предтеченский }\end{array}$ & $7(19,4 \%)$ & $9(25 \%)$ & $7(19,4 \%)$ & $13(36,1 \%)$ & & 36 \\
\hline Голутвин & $3(10,7 \%)$ & $10(35,7 \%)$ & $7(25 \%)$ & $7(25 \%)$ & $1(3,5 \%)$ & 28 \\
\hline Брусенский & $11(42,3 \%)$ & $9(34,6 \%)$ & $2(7,7 \%)$ & $4(15,4 \%)$ & - & 26 \\
\hline $\begin{array}{l}\text { Ппасо- } \\
\text { Преображенский }\end{array}$ & $1(8,3 \%)$ & $3(25 \%)$ & $3(25 \%)$ & $5(41,7 \%)$ & & 12 \\
\hline Бобренев & $2(25 \%)$ & $3(37,5 \%)$ & $3(37,5 \%)$ & - & - & 8 \\
\hline $\begin{array}{l}\text { Николаевская } \\
\text { пустынь }\end{array}$ & $1(14,3 \%)$ & $5(71,4 \%)$ & $1(14,3 \%)$ & - & - & 7 \\
\hline
\end{tabular}

Видим, что основной состав монахов тульского Иоанно-Предтеченского монастыря сформировался к началу 1690-х гг., но и в последующие годы

${ }^{39}$ РГАДА. Ф. 237. Оп. 1. Ч. 1. Л. 596. 
число монахов относительно равномерно увеличивалось. В Голутвине монастыре больше всего постригов пришлось на 1690-е гг., в Спасо-Преображенском - на 1680-е и ранее. Наибольший «стаж» монашества в последнем - почти 50 лет - имели Макарий и Авраамий. Оба были пострижены в 1653/54 г. и, очевидно, на момент составления переписной книги находились в довольно преклонных годах. В Николаевской Гнилушской пустыни основной состав монашествующих так же, как в Голутвине, сформировался в 1690-х гг. Тогда приняли постриг 5 человек. В 1695 г. в обитель пришел новый настоятель - строитель Тихон, ранее возглавлявший Соколову пустынь в Каширском уезде. Возможно, с этим связано появление в обители большого числа новых насельников. Женские Брусенский и Успенский монастыри также наиболее активно начали заселяться в 1690-е гг. Почти половина монахинь Брусенского монастыря пришла сюда после 1695 г. В Успенском монастыре основная масса насельниц постриглась в последние 10 лет (26 человек, 65\%).

Исследование показало, что социальный портрет монахов Коломенской епархии отличался от той картины, которую, например, можно видеть по материалам монастырей Вологодской епархии, где основная масса пострижеников происходила из крестьянской среды. Так, в Павлове Обнорском монастыре доля крестьян среди монахов составляла 70\% (42 человека из 60$)^{40}$, в Спасо-Нуромском — 92\% (11 из 12 человек) ${ }^{41}$. По подсчетам О.Н. Адаменко, в вологодском Спасо-Каменном монастыре «абсолютное большинство приказных монахов происходило из крестьянских семей близлежащих светских вотчин и своей монастырской вотчины» ${ }^{42}$. Е. В. Кустова, изучив монастыри Приуралья, также пришла к выводу об абсолютном преобладании среди монашествующих региона представителей податных сословий - крестьян и посадских. Причем, по ее мнению, преобладание выходцев из крестьянства в монашестве являлось общей тенденцией того времени ${ }^{43}$.

Если большинство монастырей Русского Севера и Приуралья являлись сельскими, то в Коломенской епархии насчитывалось всего 3 обители, расположенных за пределами городов, две из которых практически запустели. По крайней мере до второй половины XVII в. в состав епархии входил

${ }^{40}$ Шамина И.Н. Опись имущества вологодского Павлова Обнорского монастыря.... C. $85-88$.

${ }^{41}$ Шамина И.Н. Переписная книга вологодского Спасо-Нуромского монастыря... С. 22.

${ }^{42}$ Адаменко О.Н. Монашество Вологодского Заозерья в XVII - начале XVIII в. (по переписным книгам Спасо-Каменного и Сямженского Евфимиева монастырей) // Историческое краеведение и архивы. Вологда, 2012. Вып. 19. С. 134-140.

${ }^{43}$ Кустова Е.В. Монастыри и монашество... Т. 2. С. 10. 
также сельский по месту расположения Николаевский Венев монастырь (на момент переписи - патриарший). В нем доля крестьян была несколько выше (около 47\% ${ }^{44}$, однако все же уступала аналогичным показателям по северным монастырям.

В изучаемом регионе почти половину пострижеников монастырей составляли священно- и церковнослужители. Большая часть приходилась также на представителей служилого сословия. Доля же крестьян в среднем не превышала 15\%. В значительной мере эта картина определялась близостью территории Коломенской епархии к южным границам государства. Вероятно, на состав монашествующих повлияли и местные культурные традиции. В любом случае, проведенное исследование показало, что социальное происхождение монахов в разных регионах отличалось, а причины этих различий требуют дальнейшего изучения.

\section{Литература}

Адаменко О.Н. Монашество Вологодского Заозерья в XVII - начале XVIII в. (по переписным книгам Спасо-Каменного и Сямженского Евфимиева монастырей) // Историческое краеведение и архивы. Вологда, 2012. Вып. 19. С. 134-140.

Алатырский Троицкий мужской монастырь. Документы 1612-1703 годов/ Сост. В.Д. Кочетков, А.А. Чибис. Ульяновск, 2015.

Бакланова [Швейковская] Е.Н. Крестьянский двор и община на Русском Севере. Конец XVII - начало XVIII в. М., 1976.

Башнин Н.В. К вопросу о транспортных путях и средствах передвижения в XVII в. (по материалам приходо-расходных книг Вологодского архиерейского дома // Вестник церковной истории. 2018. № 3/4(51/52). С. 303-330.

Башнин Н.В. Опись имущества и строений Дионисиева Глушицкого монастыря 1701 г. и переписные книги вотчины Дионисиева Глушицкого монастыря 1702 г. // Вестник церковной истории. 2013. № 3/4(31/32). С. 138-177.

Башнин Н.В., Черкасова М.С., Шамина И.Н. Описи вологодских монастырей как источник по аграрной и демографической истории // Переписные книги вологодских монастырей XVI-XVIII вв.: исследование и тексты / Изд. подгот. О.Н. Адаменко, Н.В. Башнин, М.С. Черкасова при участии А.П. Анишиной, Н.А. Бараевой, Е.А. Виноградовой, А.Н. Красикова, С.Н. Смольникова, И.Н. Шаминой. Вологда, 2011.

Бульгин И.А. Монастырские крестьяне России в первой четверти XVIII в. М., 1977. Дмитриева 3.B. Вытные и описные книги Кирилло-Белозерского монастыря XVIXVII вв. СПб., 2003.

${ }^{44}$ РГАДА. Ф. 237. ОП. 1. Ч. 1. Кн. 217. 
Емченко Е.Б. Женские монастыри в России // Монашество и монастыри в России. XI-XX века: Исторические очерки. М., 2002. С. 245-284.

Жервэ Н.Н. Валдайский Святоозерский в честь Иверской иконы Божией Матери мужской монастырь // Православная энциклопедия. М., 2003. Т. 6. С. 615.

Kyстова E.B. Монастыри и монашество в социокультурной истории Приуралья в середине XVI - первой четверти XVIII в. Дис. ... д-ра ист. наук. В 2 т. Киров, 2017.

Нечаева М.Ю. Монашество Среднего Урала синодального периода: принципы формирования и социальный состав. Екатеринбург, 2019.

Описи Соловецкого монастыря XVI в.: Комментированное издание / Сост. 3.В. Дмитриева, Е.В. Крушельницкая, М.И. Мильчик; отв. ред М.И. Мильчик. СПб., 2003.

Опись строений и имущества Кирилло-Белозерского монастыря 1601 года: Комментированное издание / Сост. 3.В. Дмитриева, М.А. Шаромазов. СПб., 1998.

Опись строений и имущества Кирилло-Новоезерского монастыря 1657 г. / Публ. Т.В. Сазоновой // Белозерье. Краеведческий альманах. Вып. 2. Вологда, 1998. C. $130-165$.

Отписная книга Введенского Корнильево-Комельского монастыря переписи В.Г. Данилова-Домнина, составленная при передаче монастыря игумену Рафаилу и келарю Александру 2 декабря 1657 г. / Публ. Ю.С. Васильева // Городок на Московской дороге: Историко-краеведческий сборник. Вологда, 1994. С. 130-169.

Павел Алеппский. Путешествие антиохийского патриарха Макария в Россию в половине XVII века, описанное его сыном, архидиаконом Павлом Алеппским / Пер. Г.А. Муркос. М., 2005.

Панченко А.М. Авраамий // Словарь книжников и книжности Древней Руси. Вып. 3 (XVII в.). Ч. 1 / Отв. ред. Д.С. Лихачев. СПб., 1992. С. 34-36.

Печников М.В., Пидгайко В.Г. Коломенская епархия // Православная энциклопедия. М., 2014. Т. 36. С. 390-398.

Похилевич Л.И. Сказания о населенных местностях Киевской губернии или Статистические исторические и церковные заметки о всех деревнях, селах, местечках и городах, в пределах губернии находящихся. Киев, 1864.

Румянцеева В.С. Монастыри и монашество в XVII веке// Монашество и монастыри в России. XI-XX века: Исторические очерки. М., 2002. С. 163-185.

Румянцева В.С., Даниленко Б., прот. Андреевский монастырь в Пленницах // Православная энциклопедия. М., 2001. Т. 2. С. 350.

Смолич И.К. Русское монашество, 988-1917. Жизнь и учение старцев. М., 1999.

Соколова Н.В. Описание церковно-монастырских владений в процессе секуляризации начала XVIII в.: Опыт реконструкции (на материалах Нижегородского уезда) // Северо-Запад в аграрной истории России: Межвузовский тематический сборник научных трудов. Калининград, 2008.

Углич: материалы для истории города XVII и XVIII столетий. М., 1887. 
Черкасова М.С. Демография духовенства Устюжской епархии по данным первой ревизии 1720-1724 гг. // Церковь. Богословие. История: Материалы VII Всероссийской научно-богословской конференции, посвященной 100-летию мученической кончины святых Царственных страстотерпцев и их верных спутников. Екатеринбург, 2019. С. 314-320.

Шамина И.Н. Документы по истории Григориева Пельшемского монастыря XVII начала XVIII в. // Вестник церковной истории. 2011. № 3/4(23/24). С. 30-63.

Шамина И.Н. Опись имущества вологодского Павлова Обнорского монастыря 1701-1702 годов // Вестник церковной истории. 2010. № 1/2(17/18). С. 17-107.

Шамина И.Н. Переписная книга вологодского Спасо-Нуромского монастыря и его вотчины 1701-1702 гг. // Вестник церковной истории. 2020. № 1/2(57/58). C. 5-37.

Шамина И.Н. Переписные книги коломенских Спасо-Преображенского, Голутвина, Бобренева и Брусенского монастырей 1701 г. // Вестник церковной истории. 2017. № 3/4(47/48). С. 96-226.

Шамина И.Н. Преподобный Иннокентий Комельский и основанный им монастырь // Вестник церковной истории. 2009. № 1/2(13/14). С. 26-99. 